\title{
Beyond agriculture: the counter-hegemony of community farming
}

\section{Neil Ravenscroft • Niamh Moore • Ed Welch • Rachel Hanney}

Accepted: 11 January 2013

\begin{abstract}
In this paper we seek to understand the interplay between increasingly widely held concerns about the hegemony of industrialized agriculture and the emergence of counterhegemonic activities, such as membership of community supported agriculture (CSA) initiatives. Informed by Blackshaw's (2010) work on "liquid leisure," we offer a new leisurebased conceptualization of the tactics of counter-hegemony, arguing in the process that food politics offers a rich site for new, transitional identity formation. Using a case study of a wellestablished community farm in southeast England, we demonstrate how the community members devote themselves to transient and inconsequential activities as a means of attempting to realize a larger self-related identity project. We also demonstrate how the seemingly close inter-personal bonds typical of CSA may not reflect the permanence accorded to them, with members able willingly to leave these communities once they can no longer progress their identity project. We conclude by arguing that our findings are emblematic of society in transition, with people moving well beyond the work/leisure activity into a world in which they embody the idea and the practice of being an active co-producerin our case, of food. While recognizing that this does not necessarily mean that there is simple causality between practice and identity formation, we do argue that there is evidence of an increasing relationship between activity, time, and the performance of a new form of civil labor practice.
\end{abstract}

Key words Civil labor $\cdot$ Community supported agriculture $\cdot$ Liquid leisure $\cdot$ Co-production

\section{N. Ravenscroft (email)}

School of Environment and Technology, University of Brighton, Cockcroft Building, Lewes Road, Brighton, BN2 4GJ, United Kingdom

Email: N.Ravenscroft@ brighton.ac.uk 
Centre for Socio-Cultural Change, University of Manchester, Manchester, United Kingdom

E. Welch

School of Modern Languages and Cultures, University of Durham, Durham, United Kingdom

R. Hanney

Tablehurst Community Farm, United Kingdom

\section{Author Biographies}

Neil Ravenscroft, PhD, is Professor of Land Economy and Director of Postgraduate Studies, Science \& Engineering, University of Brighton. He is also a Director of Tablehurst Community Farm, East Sussex, UK, and chairs its Management Group.

Niamh Moore, $\mathrm{PhD}$, is Research Fellow at the Centre for Socio-Cultural Change, University of Manchester, where she works on (re)visioning an ecofeminist politics of sustainability. Dr. Moore also works with a Young Women's Group in Manchester who have their own allotment garden and who are community partners in the AHRC Connected Communities research.

Ed Welch, PhD, is Senior Lecturer in the School of Modern Languages \& Cultures, and CoDirector of the Durham Centre for Advanced Photography, University of Durham. His interest in food communities is connected with his photographic research on the representation of allotment societies in northeast England.

Rachel Hanney is a member of the Tablehurst Community Farm Management Group and was lead community partner in this research project. When not engaged in community research, she divides her time between volunteering in the Tablehurst Farm shop and running beehive-building workshops for the Natural Beekeeping Trust.

\section{Acknowledgments}

The research was funded by a grant AH/1507612/1 from the Connected Communities Programme, a cross-council research program led by the Arts and Humanities Research 
Council. An earlier version of this paper was given as a keynote speech to the 2011 Leisure Studies Association conference, Leisure in Transition: People, Policy, and Places, 5-7 July 2011, Southampton Solent University, United Kingdom. 


\section{Beyond agriculture: the counter-hegemony of community farming}

\section{Introduction}

We seek, in this paper, to bring together two convergent areas of increasing academic interest: widely held public concerns about the environmental, social, and economic impacts of industrialized agriculture; and the emergence of leisure-based counter-hegemonic activities through which people try to give meaning to their lives by addressing these concerns. We take as our starting point the increasing global recognition of the deeply political nature of food production and consumption (see, for example, Madden and Finch 2006; Desmarais 2008; Mair et al. 2008; Yan et al. 2011) and the ways in which many individuals and communities seek to challenge the dominant ideology of "global food" (Carolan 2011). We know that, for many people, counter-hegemony is expressed primarily through conscious purchase and consumption decisions (Mair et al. 2008; Sassatelli and Davolio 2010; Dunlap 2012). Yet we recognize that, for others, counter-hegemony involves a commitment to production as well as consumption activities, often through membership of intentional food communities such as community supported agriculture (CSA) projects (Cone and Kakaliouras 1995; Brown 2002; DeLind 2002; Cox et al. 2008; Dunlap 2009, 2011).

For these latter individuals, it is clear that the politics of food infuses their being, often becoming a primary conduit through which they can publicly and collectively express their concerns about conventional farming (Cox et al. 2008; Dunlap 2009; Yan et al. 2011). It is the activities of these individuals and intentional communities that concern us in this paper, as we seek to address our research question about how far membership of a CSA or other form of community farm allows people to find meaning in their lives. We see this question as fundamental to understanding contemporary Western society, characterized by what Blackshaw (2010, p. 141) has termed "liquid leisure"-a new understanding of leisure as a “... hermeneutical exercise... that provides us with our own unique view of the world... ." It is this view of the world - experienced by those involved in food communities - that we seek to capture and explore in this paper.

As this suggests, it is Blackshaw's (2010) construction of liquid leisure that provides the conceptual framing for the paper. Drawn from Bauman's (2000) work on liquid 
modernity, Blackshaw's ideas have been developed from an observation that many Western societies are on the cusp of a transition in the ways in which people understand and deploy time (Rojek 2010a, 2010b; Roberts 2011; Veal 2012). Rather than the old work/leisure dualism (Chubb and Chubb 1981; Gershuny 2000), with its implication of a developmental shift from work to leisure time (Opaschowski 1998), this transition revolves around the collapse of the work/leisure divide in a new "leisure society" informed by "...a continuum of work practices - throughout people's lives - that offer a mix of social, psychological and financial rewards" (Ravenscroft and Gilchrist 2009, p. 4). This suggests that the transition is away from activity as the defining subject of work and leisure, towards activities as contributions to a new understanding of the personal role and significance of leisure (Blackshaw 2010).

This idea, of leisure as a constructive site of personal politics, draws heavily on Aristotelian philosophy (see De Grazia 1964; Hemingway 1988), that leisure should be “... an arena for the active development of the individual as a member of the community" (Mair 2002, p. 215). It is increasingly being played out through membership of intentional food communities such as CSA, where expressions of self have the possibility of breaking many conventional social and cultural boundaries (Ostrom 2007; Dunlap 2009). Indeed, such communities are increasingly understood as offering individuals the possibility of deploying largely inconsequential leisure practices in ways that can add up to highly consequentialand transformative_ civic leisure projects (Ravenscroft and Taylor 2009).

In pursuing this argument, we want to start by rehearsing some of the key arguments about the transformative and counter-hegemonic qualities of intentional food communities as a way of understanding the meanings that have been attached to membership of such communities. We then proceed to question how far the activities associated with these communities can be understood in terms of current debates about leisure as a key site of individual meaning and identity. We will then illustrate this with a case study of one wellestablished CSA in southeast England, as a basis for exploring the extent to which CSA can be understood as a site for personal and social transition. We will conclude by drawing out a number of themes that relate to our research question, about the extent to which membership of intentional food communities can provide the context for a civil labor project that is both personal and political.

\section{The counter-hegemony of community supported agriculture}


In many Western countries, CSA has developed over the last four decades as a means by which individual people can co-operate with farmers to share the risks and rewards of growing and distributing food (Groh and McFadden 1990; Ostrom 2007; Ravenscroft and Taylor 2009) and can "...also have the opportunity to build a closer relationship with the grower and potentially other members of the CSA" (Cox et al. 2008, p. 204). While most CSAs are small, with fewer than 100 members, some are extremely large, comprising over 500 members and farming large areas of land (Saltmarsh et al. 2011).

It is tempting to suggest that the increasing popularity of CSA membership illustrates a wish on the part of many people to establish new counter-hegemonic relationships with farming and the land - ones that move beyond simple leisure activities such as walking on the land and also beyond the superficial localism (Born and Purcell 2006) of buying from farm shops and farmers markets (Brown and Miller 2008; Connell et al. 2008). Indeed, Parker (2005) has gone as far as to suggest that these relationships amount to a new construct of citizenship, in which contemporary forms of consumer citizenship are taken to a new level of sustained commitment and involvement — what he has termed "food citizenship": the "human infrastructure for negotiating alternative agrifood systems" (Stevenson 1998, p. 201). Both Parker and Stevenson claim that it is this new form of citizenship that is at the core of the shifting relationship between the public and the land-one that decenters consumerism in favor of a new life politics.

We remain to be convinced that this is really such a radical transition. Following Parker (2005), Winch (2005) and Carolan (2011), it is certainly about shortening the food chain so that citizens gain better knowledges of both the production processes and the actual producer of the food. Indeed, in some CSAs, the citizens become the producers which, when combined with highly localized farming systems such as biodynamic agriculture (Van En 1988; McFadden 2003), can make redundant the very notion of the food chain. Yet it is still essentially about how people secure a supply of food, with food remaining very much a commodity to be traded, even over short distances (see DeLind and Bingen 2008 for a discussion about the empty reification of the local). In seeking to go beyond this "greenshift," Hudson (2005, p. 12) suggests that CSA does have transformative potential, since it can represent: 
A whole new food system, one that uses dollars but is not ruled by them... Here a new economics is being practiced, economics, as if... people mattered. As if the land mattered. As if food were more than a commodity.

For Hudson, this shift in emphasis is less about forming new or alternative markets and more about decommodifying food. As such, it is an example of Rojek's (2001) "life politics." This combination of localization and citizenship has been termed "civic agriculture" (DeLind 2002; Lyson and Guptill 2004), in which the underlying philosophy is the (re)integration of people and land (what DeLind 2002 has termed "inhabitation" of the land), such that new forms of democracy emerge in ways that allow individual people to rework their relationships with the politics of land and food (Mair et al. 2008; Dunlap 2012).

This paradigm shift in thinking about land and food allied to new cultural relationships between farmers and their communities is at the core of the counter-hegemony of CSA and other intentional food communities. As Trauger Groh (Groh and McFadden 1990), one of the founders of the CSA movement in the USA, has observed, the basis of the new relationship between the public and the land is based on care: the community supporting farming and the farms supporting the community. What lies at the heart of this relationship is the generation of a new way of living with the land, in which people - the community - take explicit steps to become more responsible for the food that they eat and the care that is shown to the land and those who cultivate it. And the glue that binds this form of localization and sustainability into a new relationship between the public and the land is action, at the personal and community level. It is no less than a paradigm shift from consumer to (quasi) producer through which groups of people commit to sharing the risk and responsibility for producing food for consumption by local people. This is the basis of what McFadden (2003) has referred to as "regenerative agriculture," a form of enterprise that incorporates a community of people engaged in civil labor to produce and consume the food (and land, landscape and amenity) that they, collectively, decide to grow.

\section{Leisure in transition}

Perhaps the first question to ask in this regard is whether membership of a CSA qualifies as a leisure activity. If leisure is understood in conventional terms, as a combination of time, activity, and state of mind (Roberts 2011), then it probably is. Certainly, Mair (2002) is 
comfortable with the idea that committing time to self-development is constitutive of leisure activity, as is Blackshaw (2010, p. 120), who sees leisure as a vocation, significant not for itself but for what it can facilitate:

It is my contention that in the liquid modern world we live in, which is founded first and foremost on freedom, leisure moves steadily into its position as the principal driving force underpinning the human goal of satisfying our hunger for meaning and our thirst for giving our lives a purpose. This is the job that leisure was always cut out for, since it is that distinct realm of human activity which perhaps more than any other provides us with the thrill of the search for something and the exhilaration of its discovery.

This, then, is the transition: away from the consumption/production bifurcation towards a new understanding of leisure as a way of being, such that leisure is no longer about activity per se, but about what Blackshaw (2010, p. 142) has termed a "devotional practice" through which people render meaning to their lives. As Mair (2002) has observed, this devotional practice can lead to sustained behavior change and to the production of new identities. This is not the old consumerist connection between wealth and display, but a new paradigm related to the deployment of a continuum of productive and consumptive labor opportunities through which individuals produce and deploy their chosen behaviors and identities — which are avowedly individual and personal.

Perhaps it is of little surprise, therefore, that individuals deploy civil labor in performing civic agriculture, for they are one-and-the-same. As DeLind (2002) has suggested, the gesture of reinhabiting the land demands that the inhabitants determine a new personal politics that enables them to express their identities and achieve their desired levels of wellbeing. And this is no small matter, for it involves what Blackshaw (2010, p. 20) describes as "living dangerously" - transcending the things that people feel that they cannot do in their "real" lives. As Blackshaw claims: “... we may never be able to completely lose our social class, gender or ethnic identities, but this does not stop us trying" (2010, p. 20). Dunlap's (2011) construct of volunteers "playin' farmer" in a craft-based community of practice is a good example of living dangerously. In cases such as this, people's leisure tends to take on a devotional quality that leads them to identify their practice as a form of civil labor, performed as a service or duty to others (Rojek 2010b). 
As with any form of devotion, there is intensity to this approach to leisure practice that leads people to find association with other devotees. Superficially it can appear that the practice itself is the subject of the devotion, whether the practice is shopping, collecting artifacts, or performing civil labor within civic agriculture. Yet, as Blackshaw (2010, p. 144) cautions, people may actually be ambivalent to such practices-as practices-while remaining devoted to attaining what the practices can facilitate. As such:

... devotional leisure is experienced ... in episodes ..., and the sense of community we experience with it, when it does live, lives similarly, devoid of any kind of extended unity save for that contingently imposed on immediate events.

Following this argument, the civil labor of community agriculture may well draw people together into tight-knit association, but we should be careful in seeing this as more than a convenient alliance that allows each person to pursue their own project: themselves. This is redolent of Maffesoli's (1996) work on neo-tribes, where he asserts that the intense bonding that people feel in such situations should not be mistaken for deep friendship or connection. Rather, such affiliation is contingent on a group of people continuing to perform congruent, but individual, acts of self-identification (Bauman 2000). Of course, the affiliation (or tribal connection) will be broken when individuals no longer feel that they can, or need to, express themselves through that form of leisure practice. As Blackshaw (2010, p. 145) observes, devotional leisure is transient - all pursuits come to an end, while life itself goes on, experienced through new pursuits, and so on.

In summary, the counter-hegemonic practices of new community farmers are, indeed, emblematic of leisure in transition. At a superficial level, this transition involves a shift in the focus of activity, from the shop to the field, and with it a concomitant shift in performing the politics of food. However, following Blackshaw (2010) and Rojek (2010a, 2010b), transition is equally taking place at a deeper and more personal level, with people deploying devotional leisure practices such as community farming as a way of rendering meaning in their lives. As Blackshaw (2010) argues, it is what leisure was meant to do-and counter-hegemonic activity around the production and distribution of food is clearly one way of pursuing this goal. As a consequence, we now want to explore what it is to "live dangerously" in performing liquid leisure through a case study of one of the largest and oldest CSAs in the UK. 


\section{The civil labor of CSA: a case study of Tablehurst and Plaw Hatch Community Farms}

The first attempt to start an agricultural community in the UK was at Plaw Hatch Farm, East Sussex, in the early 1980s (see Klett et al. 1990). Although it was not long-lived, the ideas developed by the community came to fruition when a neighboring farm (Tablehurst Farm) became available in the early 1990s and a decision was taken to find a way of creating a formal CSA structure. Following lengthy discussions, a tripartite relationship was developed in which local people would create and fund a co-operative capable of owning the farm business, farmers would be employed to run the business, and a land trust would hold the farmland in perpetuity for the benefit of the farm and its community (Burkham 2010). Tablehurst and Plaw Hatch Community Farms Ltd (TPH) was established in 1995, with approximately 250 members contributing sufficient capital to purchase the business at Tablehurst and fund its launch as a community farm. Subsequent to this the co-operative continued to grow (to around 600 shareholders) and, in 2000, acquired Plaw Hatch Farm. In addition to buying shares in the co-operative, many people participated in work days on the farms, and in planning days to support the development of the CSA. While some people continue to volunteer their labor, mainly through committee membership or by working in the gardens and the shops, most members now have little day-to-day engagement with the farms, although they do attend events that are arranged throughout the year.

The two businesses now farm biodynamically (Thornton Smith 2009) approximately 300 hectares of land, employ over 25 staff, including farmers, growers, food processors, and shop staff, and have a joint annual turnover of more than $£ 1.5 \mathrm{~m}$. Each business is run by a separate management group comprising a mix of farmers and volunteers, while the co-op itself is run by an elected committee. Apart from the initial share capital contributed by the co-op, there is no community financial contribution to the working capital or running costs of the farms, and shareholders receive no direct benefits (such as dividends or price reductions) for the value of their shares. Rather, they view their share purchases as a "virtual gift" to the farms, with few shareholders having ever sought to sell or redeem their shares. It is a cliché locally that the shares represent the best purchase that any of the members have ever made.

Despite the undoubted and enduring success of the CSA, some of those who were originally involved have "drifted away" from active involvement in the farms community, while relatively few new members have joined, certainly in recent years. This led to the community deciding recently to review its progress to determine what had happened and 
why. This provided us - the researchers - with an opportunity to assist the community with its review process and offer an explanation of what has taken place. A case study approach, involving an empirical investigation of contemporary phenomena within their actual context (Yin 2009) was used for data collection and analysis. This approach was selected because the findings could be made accessible to the community members while also yielding deeply descriptive data suitable for analysis (see Flyvbjerg 2011; Uprichard 2012). In our case, the empirical data used for the investigation were drawn from a number of sources: an initial review meeting involving 70 active community members (mainly those who had been members for at least 10 years); 20 individual interviews with leading members of the community, including some of the farmers; 4 small group interviews with people who have joined the community in the last 10 years; and deep reading of a number of texts, including letters from several community members and a group of former farm apprentices, and copies of magazine articles that had been written about the farms.

In all, 125 people contributed to the research. All the interview sessions and the meeting were recorded and transcribed, and all the letters and magazine quotes were copied into digital format. All contributions have been anonymized. A process of deep reading and prescriptive content analysis of the material was then undertaken (see Krippendorff 2004), with the coding frame derived from concepts in the literature on liquid leisure. The key concepts used in the coding were related to: devotional leisure practice; the search for meaning through leisure; and living dangerously. These concepts, together with an additional one that emerged from the analysis (“drifting away"), were significant in explaining the data. The four concepts have thus been used to structure the findings.

\section{Findings: understanding civil labor}

Searching for meaning

Many of the participants spoke of their wish to find a new way of supporting agriculture that did not play into the hands of the large supermarkets and global food systems. The following observation, from a man who joined after the co-op had become established, exemplifies these motives: 
These days, people have become divorced from the food they eat, and I want my children to eat well. This is the way society needs to go, and is an answer to the fast food and supermarket approach.

Some of the founder-members of the co-op had previously been involved in the agricultural community at Plaw Hatch and were still searching for the ideal way to run such a community. What brought many of the original shareholders together was a continuing belief that agriculture could be organized differently. One example of this was expressed by a man who joined the co-op in its early years:

I remember that moment of arriving in [the community]... and feeling that something was going on. I hadn't really heard of [Rudolf] Steiner ...but I felt excited about making links with my past - the idea of making a transition with a group of like-minded people. I thought, "this is why I am here" ... I went to some meetings; I wanted to become part of the "movement" ... I felt intuitively that buying shares was spot on - the right way to go. I got involved in the work days ... I always felt that the farm spoke to me, without knowing quite where I fitted in.

These comments reflect the feelings of many others: that they connected with the idea of share ownership and with the farms themselves, but without ever quite understanding their role in the community. This is highly redolent of Blackshaw's (2010, p. 152) observation that the "point" of leisure can be elusive: the practice of leisure can provide lots of excitement and many opportunities, but the point of it may remain stubbornly out of reach. But, as the quote implies, this is not a problem in itself, as long as the practice "feels" as if it involves a step in the direction towards finding meaning. Other people spoke of being "captivated" by their sense of the farm, while many people also spoke about the "energy" and "excitement" that was palpable in the community when it became clear that the CSA might work. The next quote, by one of the founders, is typical of these comments:

I had lots of discussions with [the farmers] about the problems of maintaining the biodynamic impulse in an economic climate dominated by large-scale conventional agriculture. This would have been in the early 1990s. There was lots of enthusiasm around establishing the co-op and I was amazed when the financial goals were reached. 
The community members were not alone in their search for meaning, for this equally applied to the farmers who arrived to run the farm. Their dominant rhetoric was about the opportunity they had been given to farm in harmony with the community and the environment. They claimed that, for most of them, farming without community support would not have been possible. Some of them went further, however, to express a view that they would have chosen community farming even if they could have afforded to have farmed independently. Typical of this is a comment from a former farmer, now retired:

... we were new to all of this. We had struggled to get into farming; we weren't trained farmers. We couldn't get started. ... Even if we had had the money, we probably wouldn't have farmed on our own, because it is such an undertaking.

While the early pioneer phase may have passed, some people still join the CSA as part of their search for meaning. For some, this is about forming an active identity, reflecting a commitment to action, not just belonging, as expressed by a recent "incomer" from London:

I wanted to form new social networks having moved from London ... you don't tend to form your social networks with neighbors, but with people who have common interests ... joining the co-op is one way in which I want to build my social network. I'm joining a co-operative and ultimately I do have a vote, I do have a stake ...

The characteristic of all these people is that they have found, in the CSA, a vehicle through which they feel that they can give purpose to their lives. For the community members this is predominantly about making an active political statement about the way that they want to live their lives, and the steps (physical and financial) that they are prepared to take in order to support this gesture.

The devotional practice of community farming

Many of those who participated in the research spoke of the ways that they had contributed to the farm, certainly in the early years. For them, contributing work was a way of fulfilling 
their search for meaning, with the quality of the work less important than the gesture of the work itself. Many of the practices that were identified were, in Roberts' (2011) terms, inconsequential, as described by one of the original co-op members:

I made endless posters for different things. I remember the "crisis" poster that was put up everywhere; and the public meetings; and endlessly baking cakes and making tea - and I don't remember what for-we were consumed with the nitty gritty, not the content.

Another example of this devotion to the farm concerns a woman who felt that she could not contribute to the intellectual and spiritual development of the farms, but she was good at providing support to the farmers:

My connection is to the farm and the people I know at the farm; I feel that I can help them; I can do what they ask. I don't have an agenda; I can respond-if they want an open day, I'll do one for them. It isn't me giving my agenda to them; all I am offering is support. My connection is with Tablehurst; I live close; I can hear the cows; I can walk up there and I feel privileged to belong...

Attending meetings, undertaking administration, laboring, running and attending events, fund raising, making cakes, and other such activities are the stuff of everyday life for many volunteers in many fields of leisure activity (Stebbins 1992, 2009). Yet, when viewed within the context of their civil labor, the meanings behind these activities were much greater than the significance of the activities themselves. Indeed, it is clear that these practices addressed some of the arenas that Roberts (2011) has described as constitutive of "big leisure," particularly enhancing well-being and expressing identities.

In contrast to the inconsequential activities of most members, some people took on official roles, which they enjoyed and felt honored to undertake. One long-term member expressed it thus:

It is happenstance that I got onto the [farm] management group. It is very intense; sometimes challenging; always interesting. I want to work towards a deeper and more holistic way of seeing ... I am still fascinated with the farm on this levelthe consciousness of new possibilities ... what appears on the outside to be a 
business is so much more when you look internally; it is fascinating and mystifying at the same time.

Yet, for the farmers, these roles are pivotal to the success of the farms, in terms of access to bodies of knowledge and in terms of expressing community support and providing what is understood locally as a "warmth body" around the farmers:

I would like to say that I feel the management groups have been crucial in the development of both of the farms. ... the farms have made a tremendous achievement in generating such enthusiasm in people who are not farmers - with a common purpose and sharing of risk.

Allied to this observation was a qualification, common to most of the farmers, that farming on behalf of the community is unrelenting hard work-perhaps all the more so because it is the community's money that is financing it. One farmer, remembering when the farms started, suggested that the commitment of the farmers was just as devotional as that of the members:

... we weren't employees with regular holidays and overtime; we worked until we died ... there was no [alternative]; we didn't have real wages ... we dipped into savings just to live.

And the reason for this, of course, was a duty to manage the farm on behalf of the community:

It's not our farm, it's the community's farm. Most people just want to feel connected to the countryside, but without the lonely responsibility of all that hard slog and worry. That's why we're here - to provide the perfect compromise.

It is interesting that these views are highly reminiscent of many of the early CSAs studied by Groh and McFadden (1990), where the farmers were reticent about claiming a decent wage, preferring instead to subsidize the CSA. As Groh and McFadden found, this often contributed to the CSAs failing, or having to be "rescued" by new farmers. While these extremes have not been experienced at $\mathrm{TPH}$, it is clear that the devotional wishes of the 
community carry with them a burden on the farmers: that they provide an environment in which non-farmers can, in Blackshaw's (2010, p. 20) terms, "live dangerously" by doing what they cannot do in their everyday lives. To do the civil labor of the "non-active" farmer is, ultimately therefore, dependent on the continuous (hard physical and mental) work of the farmers, something that was appreciated by those who felt that they had benefitted personally from their civil labor at the farm:

Tablehurst connects me with the ground and gives balance to my life. ... I see this [membership of the CSA] as a great privilege. I'm working with my neighbors and the farmers, who are a fantastic bunch of inspirational people.

\section{Living dangerously}

Few of those who contributed to the research sought to blur the boundaries between their voluntary - if devotional - contributions to the farm and the work performed by the farmers. For most of them it was enough to be involved, without the need to identify more closely with the work of the farm and farmers. Even the exceptions to this did not stray far into dangerous territory, as exemplified in this claim:

I always make sure I have time to help out with the lambs in the spring. It's an extraordinary experience...there's a sense of guardianship over the ewes.

While making sure that he is identified as someone with skill and knowledge of farming, this person also makes it clear that this activity remains, for him, a voluntary gesture to the farm. For others, the gesture was about getting involved: they wanted to work alongside the farmers, to make a physical contribution to the farm in the way championed by Liz Henderson and others in the USA (see Henderson and van En 2007). The following quote, from a woman who joined soon after the co-op started, is typical:

... [there were] lots of enthusiastic work days, lots of people turning up right from the beginning. ... the farm had a need for labor; but it was much more that the farm needed the community to be involved, and many wanted to be involved - this was a crisis; we did a lot in a short space of time ... 
The rhetoric of crisis is interesting here; it is part of a broader culture that positioned the farms (and farmers) as weak and needing help and support. This sense of the strong community coming to the aid of the weak farm allowed many people to feel that they were significant, even if they knew little about farming. For them, this was the essence of CSA: it was about "living" the farm as a member of the broader farm team, even if the "reality" was not quite as they had remembered it:

There were not that many workdays and they were often fairly haphazard and often not well attended. They have taken on a mythology - but they had lived their day very soon. ... I remember weeding as tough ... (it was) all too much for people who were only used to gardening. Truth is that this was a relatively shortlived phenomenon, but people loved it at the time, being with others and getting your hands in the soil. ... But numbers dwindled; it was hard to ensure that there was meaningful work to be done ... it got in the way of farming (ha ha) ...

In a similar vein, some other people probably over-stated their involvement with the community and blurred their identity of themselves as farming pioneers. This was often expressed as enjoyment of the role of owner, underpinning what had been achieved through this approach to farming. The following example of this was articulated by a founder-member of the co-op:

... It has truly been a community effort for the benefit of all who value responsible agriculture and local quality food on your table. The gesture of selfless gift finance underpins every aspect of our local community supported agriculture; long may it stay that way!

It is particularly interesting here that what commenced as share ownership, with ideas about community participation in farming business, has been reconstructed as a gift from the community to the farm. And with this - in Hyde's (2006) sense of implicit reciprocitycomes a warning: what the community gifted, the community continues to control, despite the increasing passage of time since the "gifts" were made. For some of those involved, it appears that this is very much part of living dangerously: that the life lived in this way can be curtailed at any time, almost without warning, as was the case with this woman: 
Plaw Hatch at that time ... was surrounded by an enthusiastic body of warmth and there was vitality, with everybody ... working together. Families would meet at [the farm] every other Saturday and would be set to work ... This was an exciting time with everyone socializing and mucking in. ... There was a real sense of coming together with everybody "living" the farm. This lasted for about

a year or two when I was utterly shocked to receive a phone call suggesting certain individuals were not pulling their weight. This left a bad feeling; we all had busy lives and sometimes were not able to give our time ...

Duty done

As the last quote suggests, the community has not been without challenges, and a number of the early pioneers have left, for various reasons often related to their "dangerous living" coming to an end. In contrast to being "forced out," many people felt that the process of leaving the community was akin to having done their duty-having achieved what they intended to do and now being ready to move on. Typical of this was a comment by a longterm member:

I first supported the farms as a social impulse - many of us did. That is no longer necessary, but I feel really connected with the farms every time I go to shop, or to an event.

Others offered a similar explanation for their decision to stand back:

The farms no longer need my support. They are independent and strong. I can now choose when I visit and what I do.

In contrast to these supportive views, some people felt as if they had been let down, and that the community no longer necessarily reflected their personal understandings of their identity. One person, originally involved in the politics of establishing the legal structure of the CSA but no longer involved in any official capacity, suggested that his interest was now no more than as a consumer: 
If the farms are producing food that I find valuable, then I will support them. I won't support them only out of ideology ... am I cynical or enlightened? I'm absolutely comfortable [with my position on this]

In a similar way, another ex-community member suggested, obliquely, that the farms no longer reflect their way of thinking and feeling, which is not to deny the value of the farms, but to remind them of their duty to maintain their links to community:

... I am not looking for greater involvement, I think farms like this are incredibly important in the wider world ... you only want to preserve things with which you have created a relationship ... to be a [member] is to believe that the farm needs to exist ... and for this the community must experience at first hand what the farms are ... people will only be there when the farm needs them if they know why the farm exists and why it needs them ...

In the main, however, people moved away from the community as it ceased to have value for them in their life journey. One person, who is still involved in the community but knows many people who are not, observed that:

Community is a contingent thing-people come into relation with others; this becomes intense, then they pull away ... it's a merry-go-round-people get on and off; some want a long ride and others have enough very quickly.

This merry-go-round was certainly felt by the farmers, who at one time relied on volunteers to help at major harvest times:

At the beginning we did a lot of veg[tables]—potatoes and leeks. It was like a prison camp at harvest, the mud-out digging leeks, and washing them in cold water and sliding heavy crates over the mud down the field. I remember the students from the college coming down to help—-students en masse used to come and help, but over time this fell away. Some still came 'till the point where you had to pay them to come, and even then they wouldn't come. 
This certainly led some people to question whether the concept of "community farm" remains relevant to Tablehurst and Plaw Hatch, and in what form. A number of people, echoing earlier comments, suggested that what was now important to people were the nice farm shops set in wonderful countryside and with a rich recent history:

And what of the balance between paid and non-paid work? Are we becoming less community because most of us no longer work physically on the farm? ... it's important to articulate what the community farm is about ... but it is also important to understand that we don't have the answers. What we do have is the being of the farms, the shops, the land. These are powerful and the totality that we are here has power; ... it lives in the community, even for those who do not come to the farm, nor belong to the co-op.

\section{Conclusions}

What we have offered here are necessarily glimpses into a complex and messy world of civil labor, insofar as it reflects a number of inconsequential, but associated, practices that together offer insights into how people deploy leisure to produce meaning in their lives. As we have seen, there are four dominant narratives at play in the case study, relating very much to Blackshaw's (2010) construct of liquid leisure. There is no doubt, for example, that many of those involved in the Tablehurst and Plaw Hatch community farms became involved as part of their personal search for meaning in their lives. What the farms offered was a relatively easy (for those with some disposable money) way of uniting with others to perform the counter-hegemonic act of growing, distributing, and consuming local food. For many this was about "fronting up" on the issue of local food: performing membership through civil labor and making this performance visible to others as a challenge to them to recognize the politics of local food. To this extent, Mair's (2002, p. 213) contention that civil leisure “ ... can take up some of the room created by the lapse in formal political activism" is certainly being played out at Tablehurst and Plaw Hatch Community Farms.

And, in this context, "played out" means performing with devotion a multitude of relatively minor and inconsequential activities that contribute to the operation of the farms. While a mythology seems to have developed around what activities have been performed, and over what period, it is clear that the activities themselves are rather less important than 
their signification as practices that give meaning to the personal and political act of membership of the farms community. This is certainly redolent of Blackshaw's (2010) description of the ambivalence of devotional leisure practice - that it matters less what the practice is than it does that the practice is being performed as a vocation. It is further clear that many of those involved have experienced their devotional leisure as episodic: they have come together at key moments, such as harvest, to work together and to experience intense moments of bonding that are understood individually and collectively as experiences of community.

For some of those involved, these moments of bonding have allowed them to experiment with their identity, if only briefly. These moments are emblematic of Blackshaw's (2010) construct of living dangerously. While few people were willing to claim the status of farmer, or of food activist, many used a rhetoric that suggested that they were "more than a volunteer" and that their devotional practices at the farms gave them a status beyond that of mere consumers. The rhetoric here was very much about "having time" to give to the farms when they were in need (often constructed as "crisis") and about how those involved worked alongside the farmers - in effect becoming one with the farmers for that period of time. While undoubtedly filling a need at the farms, it should equally not be doubted that, for these people, such activities were very much about deepening their own projects, thus "... limiting the contingency of [their] place in the world by transcending it ..." (Blackshaw 2010, p. 20).

Finally, underlining Blackshaw's (2010) reading of the transience of devotional practice, many people have left the community, often because they feel that they have done their duty. Typically here the rhetoric is about the strength of the farms meaning that they no longer need volunteer labor as they once did. For some, this amounts to a crisis in their understanding of community - in effect that community has left them. However, others observe that there is always movement in and out of communities, and there is no reason to suppose that this one is any different, even if it has seemed so important and central to many people's lives. Indeed, this does seem to be the case, for many former members talked of their delight of continuing to shop at the farms and to see the farms continue to grow.

In conclusion, therefore, we argue that the dynamism of this intentional community can be understood by reference to the conceptual tools offered by Blackshaw's (2010) reading of liquid leisure. We further suggest that the case study offers an insight into what is no less than a paradigm shift in our understanding of leisure, for unlike Stebbins' (1992) neoclassical construct of leisure as meaningful activity, the majority of the participants in the CSA did not routinely view their activities and deployment of time as leisure per se. Rather, 
they viewed their participation as a part of their wider lives, part of their personal project that Rojek (2010b) has recognized as civil labor. And this is what distinguishes this new agenda for leisure research: a declining interest in singular, but identifiable leisure practices, and a heightened interest in the project that lies behind the deployment of these practices- "the display of credibility, relevance, and competence in our 'voluntarily' chosen 'free' time activities [that] speaks to others about who we are, what we hold to be valuable and how we can make a difference" (Rojek 2010b, p. 3).

This very much draws us back to the origins of contemporary leisure studies, where we have routinely defined leisure as a combination of time, activity, and state of mind without, certainly recently, stopping too long to decide what we mean by this. As Roberts (2011, p. 5) observes, “ ... leisure studies [has] largely withdrawn from examining ... leisure in its entirety and its role in society." Instead we have become dominated by activitypractice - and the times and spaces in which it occurs. What this case study of civic agriculture reminds us is that, for many people, time and activity are such elastic concepts that they no longer have meaning in themselves. Rather, they are now routinely understood and deployed in performing projects of deep personal meaning, such as the counterhegemony of local and community food production and consumption. This is highly significant to our original observations, because it has allowed us to refigure our understanding of leisure theory through studying the performance of these counterhegemonic acts. As a result of this we see that we are faced with nothing less than a new construction of (liquid) leisure as essentially "non-leisure." And in this new, liquid leisure world, the members of the Tablehurst and Plaw Hatch Community Farms are busy constructing meaningful lives outside of conventional work and leisure activities that bear all the hallmarks of a big leisure project, although it is no longer understood (or performed) in these terms.

\section{References}

Bauman, Z. 2000. Liquid modernity. Cambridge: Polity Press.

Blackshaw, T. 2010. Leisure. Abingdon: Routledge.

Born, B., and M. Purcell. 2006. Avoiding the local trap: scale and food systems in planning research. Journal of Planning Education and Research 26: 195-207. 
Brown, C., and S. Miller. 2008. The impacts of local markets: a review of research on farmers markets and community supported agriculture. Paper presented at the American Agricultural Economics Association meeting, Orlando, FL.

Brown, S.L., ed. 2002. Intentional community: an anthropological perspective. Albany, NY: SUNY Press.

Burkham, C. 2010. Emerging forms of ownership for farms and food businesses. Paper presented at the 2010 National Conference of the Biodynamic Farming and Gardening Association, Biodynamics and the future of agriculture: growing the food revolution, Three Fold Educational Center, Chestnut Ridge, NY, 30 Sept-3 Oct 3.

Carolan, M.S. 2011. Embodied food politics. Farnham: Ashgate Publishing Ltd.

Chubb, M., and H.R. Chubb. 1981. One third of our time? An introduction to recreation behavior and resources. New York: John Wiley \& Sons Inc.

Cone, C.A., and A. Kakaliouras. 1995. Community supported agriculture: building moral community or an alternative consumer choice. Culture and Agriculture 51/52: 28-31.

Connell, D.J., J. Smithers, and A. Joseph. 2008. Farmers' markets and the "good food" value chain: a preliminary study. Local Environment 13: 169-185.

Cox, R., L. Holloway, L. Venn, L. Dowler, J. Ricketts Hein, M. Kneafsey, and H. Tuomainen. 2008. Common ground? Motivations for participation in a community supported agriculture scheme. Local Environment 13: 203-218.

De Grazia, S. 1964. Of time, work, and leisure. New York: Twentieth Century Fund/Anchor Books.

Delind, L. 2002. Place, work, and civic agriculture: common fields for cultivation. Agriculture and Human Values 19: 217-224.

DeLind, L.B., and J. Bingen. 2008. Place and civic culture: rethinking the context for local agriculture. Journal of Agricultural and Environmental Ethics 21: 127-151.

Desmarais, A.A. 2008. The power of peasants: reflections on the meanings of La V1a Campesina. Journal of Rural Studies 24: 138-149.

Dunlap, R. 2012. Recreating culture: slow food as a leisure education movement. World Leisure Journal 54(1): 38-47.

Dunlap, R. 2011. Playin' farmer: leisure experiences in a craft-based community of practice. International Journal of Qualitative Studies in Education 08/2011 DOI:10.1080/09518398.2011.604648.

Dunlap, R. 2009. Taking Aunt Kathy to dinner: family dinner as a focal practice. Leisure Sciences 31(5): 417-433. 
Flyvbjerg, B. 2011. Case study. In The Sage handbook of qualitative research, ed. N. Denzin and Y. Lincoln, 4th ed., 301-316. Thousand Oaks, CA: Sage.

Gershuny, J. 2000. Changing times: work and leisure in postindustrial society. Oxford: Oxford University Press.

Groh, T., and S. McFadden. 1990, Farms of tomorrow: communities supporting farms, farms supporting communities. London: Steiner Books

Hemingway, J.L. 1988. Leisure and civility: reflections on a Greek ideal. Leisure Sciences 10(3): 179-191.

Henderson, E., and R. Van En. 2007. Sharing the harvest: a citizen's guide to community supported agriculture. White River Junction, VT: Chelsea Green Publishing Company.

Hudson, A. 2005, CSAs cropping up around the globe. Critique: A Worldwide Journal of Politics. Spring 2005.

Hyde, L. 2006. The gift. How the creative spirit transforms the world. Edinburgh: Canongate Books Ltd.

Klett, M., R. Moore, R., and A. Carnegie. 1990. Growing together: why should we bother? Forest Row, East Sussex: International Bio-dynamics Initiative Group.

Krippendorff, K. 2004. Content analysis: an introduction to its methodology. 2nd edition. Thousand Oaks, CA: Sage.

Lyson, T., and A. Guptill. 2004. Commodity agriculture, civic agriculture, and the future of US farming. Rural Sociology 69: 370-385.

Madden, E.M., and M.L. Finch. 2006. Eating in Eden: food and American utopias. Lincoln, NE: University of Nebraska Press.

McFadden, S. 2003. The history of community supported agriculture, part 2: CSA's world of possibilities. The New Farm (www.newfarm.org).

Maffesoli, M. 1996. The time of the tribes: the decline of individualism in mass society. London: Sage.

Mair, H. 2002. Civil leisure? Exploring the relationship between leisure, activism, and social change. Leisure/Loisir 27(3-4): 213-237.

Mair, H., J. Sumner, and L. Rotteau. 2008. The politics of eating: food practices as critically reflexive leisure. Leisure/Loisir 32(2): 379-405.

Opaschowski, H. 1998. The future of leisure, culture, and tourism-The challenge for politics and society. In Leisure, culture, and tourism in Europe: the challenge for 
reconstruction and modernization in communities, ed. W. Nahrstedt and T. Pancic Tombol, 15-26. Bielefeld: Institut fur Freizeitwissenschaft und Kulturarbeit.

Ostrom, M.R. 2007. Community supported agriculture as an agent of change: is it working? In Remaking the North American food system: strategies for sustainability, ed. C.C. Hinrichs and T.A. Lyson, 99-120. Lincoln, NE: University of Nebraska Press.

Parker, G. 2005. Sustainable food? Teikei, co-operatives, and food citizenship in Japan and the UK. Working Papers in Real Estate \& Planning 11/05. University of Reading, Reading.

Ravenscroft, N., and P. Gilchrist. 2009. The emergent working society of leisure. Journal of Leisure Research 41(1): 23-40.

Ravenscroft, N., and B. Taylor. 2009. Public engagement in new productivism. In What is land for? The food, fuel, and climate change debate, ed. M. Winter and M. Lobley, 213-232. London: Earthscan.

Roberts, K. 2011. Leisure: the importance of being inconsequential. Leisure Studies 30(1): 520.

Rojek, C. 2010a. Leisure and emotional intelligence. World Leisure Journal 52(4): 240-252.

Rojek, C. 2010b. The labor of leisure: the culture of free time. London: Sage.

Rojek, C. 2001. Leisure and life politics. Leisure Sciences 23: 115-125.

Sassatelli, R., and F. Davolio. 2010. Consumption, pleasure, and politics: Slow Food and the politico-aesthetic problematization of food. Journal of Consumer Culture 10(2): 202232.

Saltmarsh, J., J. Meldrum, and N. Longhurst. 2011. The impact of community supported agriculture. Bristol: Soil Association.

Stebbins, R.A. 2009. Leisure and consumption. Common ground/separate worlds. Basingstoke: Palgrave Macmillan.

Stebbins, R.A. 1992. Amateurs, professionals, and serious leisure. Montreal: McGill University Press.

Stevenson, G.W. 1998. Agrifood systems for competent, ordinary people. Agriculture and Human Values 15: 199-207.

Thornton Smith, R. 2009. Cosmos, earth, and nutrition: the biodynamic approach to agriculture. Forest Row, East Sussex: Sophia Books.

Uprichard, E. 2012. Describing description (and keeping causality): the case of academic articles on food and eating. Sociology DOI: 10.1177/0038038512441279. 
Van En, R. 1988. Basic formula to create community supported agriculture. Great Barrington, MA: Indian Line Farm.

Veal, A.J. 2012. The leisure society II: the era of critique, 1980-2011. World Leisure Journal 54(2): 99-140.

Winch, R. 2005. Community supported agriculture: a model for combating distance. Sustainable Development Final Research Paper ENVI 313. Center for Environmental Studies, Williams College, Williamstown, MA.

Yan, S., C. Cunwang, L. Peng, W. Tiejun, and C. Merrifield. 2011. Safe food, green food, good food: Chinese community supported agriculture and the rising middle class. International Journal of Agricultural Sustainability 9(4): 551-558.

Yin, R.K. 2009. Case study research: design and methods. Thousand Oaks, CA: Sage. 